\title{
Alloy Formation by Electrodeposition of Niobium and Aluminium on Gold from Chloroaluminate Melts
}

\author{
Nataša M. Vukićevićl ${ }^{1}$,Vesna S. Cvetković ${ }^{1, *}$, Ljiljana S. Jovanović ${ }^{2}$, Sanja I. Stevanović ${ }^{1}$, \\ Jovan N. Jovićevic ${ }^{1}$ \\ ${ }^{1}$ Institute of Chemistry, Technology and Metallurgy, University of Belgrade, Njegoševa 12, 11000 \\ Belgrade, Serbia, PAK 125213 \\ ${ }^{2}$ Faculty of Scences, University of Novi Sad, Trg D. Obradovića 3, 21000 N. Sad, Serbia. \\ *E-mail: v.cvetkovic@ihtm.bg.ac.rs.
}

doi: $10.20964 / 2017.02 .34$

Received: 3 October 2016 / Accepted: 8 December 2016 / Published: 30 December 2016

\begin{abstract}
Niobium and aluminium have been electrodeposited from inorganic chloroaluminate melts onto gold substrate at $473 \mathrm{~K}$. The melts were prepared from an equimolar mixture of $\mathrm{AlCl}_{3}+\mathrm{NaCl}$ with niobium added by anodic dissolution. It was found that aluminium and niobium underpotential deposition on gold precedes overpotential deposition of niobium and subsequent aluminium deposition. Niobium was overpotentially deposited individually and co-deposited with aluminium. Applied electrochemical techniques (linear sweep voltammetry, polarization, open circuit and potential step) indicated, then physical analytical methods (scanning electron microscopy, energy dispersive spectrometry, atomic force microscopy and X-ray diffraction) confirmed formation of several niobium-aluminium, niobiumgold and aluminium-gold alloys in niobium and aluminium underpotential as well as in niobium and aluminium overpotential regions.
\end{abstract}

Keywords: Niobium, Aluminium, Gold, Metal deposition, Alloy formation, Chloroaluminate melt

\section{FULL TEXT}

(C) 2017 The Authors. Published by ESG (www.electrochemsci.org). This article is an open access article distributed under the terms and conditions of the Creative Commons Attribution license (http://creativecommons.org/licenses/by/4.0/). 